\title{
Effects of Drip Irrigation Configuration and Rate on Yield and Fruit Quality of Young Highbush Blueberry Plants
}

\author{
David L. Ehret ${ }^{1}$, Brenda Frey, Tom Forge, and Tom Helmer \\ Pacific Agri-Food Research Centre, Agriculture and Agri-Food Canada, \\ P.O. Box 1000, Agassiz, British Columbia, Canada V0M 1 AO
}

\author{
David R. Bryla \\ U.S. Department of Agriculture, Agricultural Research Service, Horticultural \\ Crop Research Unit, 3420 NW Orchard Avenue, Corvallis, OR 97330
}

Additional index words. Vaccinium corymbosum, anthocyanin, antioxidant, evapotranspiration, fruit firmness, nutritional health benefit, shelf-life, soil water potential

\begin{abstract}
A 4-year study was conducted to establish the effects of drip irrigation configuration and rate on fruit yield and quality of young highbush blueberry plants (Vaccinium corymbosum L. 'Duke'). Plants were grown in a silt loam soil on raised beds and were non-irrigated or irrigated using either one or two lines of suspended drip tape. Each line configuration had in-line emitters spaced every 0.3 or $0.45 \mathrm{~m}$ for a total of four drip configurations. Water was applied by each drip configuration at two rates, a moderate rate of $5 \mathrm{~L} /$ plant per irrigation event, and a heavy rate of $10 \mathrm{~L} /$ plant. The frequency of irrigation was guided by measurements of soil matric potential. Irrigation was applied each year, and plants were cropped beginning the second year after planting. Rainfall was above normal in the first 2 years of the study, and differences in soil moisture were most evident in the last 2 years, in which soil matric potential increased with irrigation volume. Neither the number of irrigation lines nor emitter spacing had an effect on yield or fruit quality. Yield was unaffected by irrigation rate until the fourth year after planting and was only higher when $5 \mathrm{~L} /$ plant was applied. The yield increase was the result of differences in fruit weight during the second of two harvests and was associated with delays in fruit maturation. Irrigation affected plant mineral concentrations but leaves and berries responded differently; affected minerals tended to decrease in leaves but increase in the fruit. Many irrigation-induced changes in fruit quality were evident 1 or 2 years before changes in yield. Higher irrigation volume increased fruit size and water content but reduced fruit firmness and soluble solids. Irrigation reduced fruit water loss during storage and thereby promoted longer shelf life. Irrigation also resulted in a change in anthocyanin composition in the fruit but did not affect antioxidants or total anthocyanin content.
\end{abstract}

Blueberry is a rapidly expanding component of the small fruit sector in the Pacific Northwest of North America. Between 1992 and 2003, acreage planted to highbush blueberry in Oregon, Washington, and British Columbia increased 124\%, 78\%, and 122\%, respectively (Strik and Yarborough, 2005) and the trend continues today. Almost all blueberry growers irrigate through the summer in an effort to match water availability to plant water demand. Of the various types of irrigation systems available, drip is becoming the most widely used in blueberry. Drip irrigation guidelines are available for horticultural crops grown in British Columbia (Van

Received for publication 6 Dec. 2011. Accepted for publication 30 Jan. 2012.

We are grateful to the BC Blueberry Council and the AAFC Developing Innovative Agri-Products (DIAP) program for financial assistance; to Ben Frey, Elyse Hofs, Russel Warwick, Taylor Holland, Albert Tsou, and June Dawson for plot work; to Albert Tsou for technical assistance; and to Mark Sweeney for horticultural advice.

${ }^{1}$ To whom reprint requests should be addressed; e-mail david.ehret@agr.gc.ca. configurations and rates on blueberry production. Treatments were imposed beginning the first year after planting, and the effects on yield and fruit quality were followed as the plants matured.

\section{Materials and Methods}

Study site. A 0.15-ha field of northern highbush blueberry (Vaccinium corymbosum L. 'Duke') was established at the Pacific Agri-Food Research Center, Agassiz, British Columbia, Canada (lat. 49 $14^{\prime} 33^{\prime \prime} \mathrm{N}$, long. $\left.121^{\circ} 45^{\prime} 35^{\prime \prime} \mathrm{W}\right)$ in Oct. 2006. Field preparation in the spring of 2006 involved ploughing, discing, and the application of 90S elemental sulfur (Terra Link Horticulture Inc., Abbottsford, British Columbia, Canada) at a rate of 1120 $\mathrm{kg} \cdot \mathrm{ha}^{-1}$ to lower the soil $\mathrm{pH}$ from 5.6 to 5.0. Soil at the site was a moderately well-drained Monroe series (eluviated eutric Brunisol) silt loam. The field remained fallow until September at which time it was subsoiled and raised beds, $1 \mathrm{~m}$ wide and $0.2 \mathrm{~m}$ high, were created in a north-south orientation. Twoyear-old plants obtained from a local commercial nursery (JRT Nurseries, Abbottsford, British Columbia, Canada) were transplanted into the beds at a spacing of $1 \mathrm{~m}$ apart within rows and $3 \mathrm{~m}$ apart between rows. Beds were topped with $\approx 8 \mathrm{~cm}$ of new Western hemlock (Tsuga heterophylla Sarg.) and douglas-fir (Pseudotsuga menziesii Franco) sawdust mulch every other year. All areas between and around beds were seeded to $30 \%$ fescue and $70 \%$ perennial rye grass (Alleyway Agricultural Mix; Richardson Seed, Abbottsford, British Columbia, Canada).

Experimental design. Nine irrigation treatments were arranged in a randomized complete block design and included all combinations of one or two lines of drip tape (DLT Heavywall Dripperline; Netafim, Fresno, CA), two drip emitter spacings, and two different volumes of irrigation (moderate and heavy) plus a non-irrigated control. Each treatment plot consisted of one row of six plants used for measurements. The treatments were randomly arranged in the blocks in two sets of five rows. Two pairs of blocks were replicated three times for a total of six replicates per treatment; note that one plot of plants in each block (i.e., Plot 10) was not used in the study. A guard row of blueberry was planted on each side of the block pairs and a guard plant was planted on each end of the plot pairs. Each plot pair was separated by a $2-\mathrm{m}$ wide walkway. The single drip irrigation line was suspended over the center of the planting bed, whereas the two lines of drip were located $19 \mathrm{~cm}$ from the center on each side of the bed. The drip lines were attached to catch wires suspended at a height of $\approx 0.6 \mathrm{~m}$ and had $1-\mathrm{L} \cdot \mathrm{h}^{-1}$ in-line emitters spaced every 0.3 or $0.45 \mathrm{~m}$. Water was applied by each drip configuration at rates of 5 and $10 \mathrm{~L} /$ plant per irrigation event in the moderate and heavy irrigation treatments, respectively. This translates into 17,935 and $35,870 \mathrm{~L} \cdot \mathrm{ha}^{-1}(7,260$ and $14,520 \mathrm{~L} /$ acre $)$ in the moderate and heavy irrigation treatments, respectively. 
Irrigation first began on 15 July 2007 and was applied annually for the duration of the study. As a guide, irrigation was initiated when the average soil matric potential $\left(\Psi_{\mathrm{m}}\right)$ in the most heavily irrigated treatments was 20-25 $\mathrm{kPa}$. Irrigations were initiated manually and applied using a Harrow Fertigation Manager (Climate Control Systems, Leamington, Ontario, Canada). The treatments were not irrigated simultaneously but were all irrigated within a $7-\mathrm{h}$ period on the same day. Depending on the weather, irrigations began in May, June, or July each year and continued through August or September. The total volume of water applied to the moderate and heavy irrigation treatments was 45 and $90 \mathrm{~L} /$ plant in 2007, 20 and $40 \mathrm{~L} /$ plant in 2008, 65 and $250 \mathrm{~L} /$ plant in 2009, and 220 and $440 \mathrm{~L} /$ plant in 2010, respectively. Hence, the heavy irrigation treatment received twice as much water annually as the moderate treatment, except in 2009 when it received 3.8 times as much as a result of additional irrigation events. The proportion of water applied up to the final harvest was $50 \%, 38 \%$, and $59 \%$ in 2008,2009 , and 2010, respectively.

Field management. Plants were fertilized with $15 \mathrm{~N}-8 \mathrm{P}-11 \mathrm{~K}$ (Berry Blend fertilizer; Terra Link Inc., Abbottsford, British Columbia, Canada) in two broadcast applications each spring. Annual rates applied in 2007, 2008, 2009, and 2010 were 40, 57, 93, and $153 \mathrm{~g} /$ plant, respectively, as recommended in the British Columbia berry grower guide (BCMAL, 2009). Soil $\mathrm{pH}$ was measured in $2 \mathrm{~cm} \times 30-\mathrm{cm}$ samples collected from the top $30 \mathrm{~cm}$ of the planting (after sawdust was removed) each fall in all treatments and was always within the 4.5 to 5.2 range recommended for blueberry (BCMAL, 2009). Flowers were removed in the spring during the first year after planting, and plants were cropped and harvested beginning the next year. At flowering each year, a honeybee hive was positioned at the north end of the plot area to facilitate pollination. Bird netting was installed above and around all six blocks during berry ripening. Plants were pruned annually each winter according to industry standards (BCMAL, 2009). In early spring of each year, the perimeter of the sawdust-covered plots was sprayed with Touchdown Total herbicide (Sygenta Crop Protection Canada Inc., Guelph, Ontario, Canada) for control of annual and perennial grasses and broadleaf weeds. In 2009 and 2010, plants were treated for Bruce spanworm (Operophtera bruceata) using Dipel 2XDF (Bacillus thuringiensis) (Valent Canada Inc., Guelph, Ontario, Canada) and in 2010 and 2011 plants were sprayed with Pristine (boscalid, pyraclostrobin) fungicide (BASF Canada Inc., Mississauga, Ontario, Canada) and Switch (cyprodinil, fludioxonil) fungicide (Sygenta, Plattsville, Ontario, Canada) for the control of green fruit botrytis.

Measurements. Rainfall, photosynthetically active radiation, relative humidity, and air and soil temperature were recorded for 2007-2010 at a meteorological station (HOBO U30 Weather Station, Onset, Bourne, MA) positioned $20 \mathrm{~m}$ from the plots. Daily potential evapotranspiration $\left(\mathrm{ET}_{\mathrm{o}}\right)$ was measured with an atmometer (ETgage Model E; ETgage Company, Loveland, CO) fitted with a Style \#30 diffusion cover. The atmometer was placed within the plots at a height equivalent to the top of the plant canopy. Blueberry evapotranspiration (ET) was calculated by multiplying $\mathrm{ET}_{\mathrm{o}}$ by a crop coefficient of 0.27 derived from a lysimeter study on highbush blueberries of similar age and planting density with manual watering (Storlie and Eck, 1996).

Soil $\Psi_{\mathrm{m}}$ was measured intermittently at a depth of $30 \mathrm{~cm}$ with tensiometers in 2007 and daily with granular matrix sensors (Watermark Model 900M Monitors; Irrometer, Riverside, CA) in 2008-2010. Two tensiometers or sensors were buried in two or three plots per treatment, respectively; one was located halfway between two plants in the center of the plot and in the middle of the bed, and the other was located $19 \mathrm{~cm}$ from the middle of the bed on either side of the plant row. Thus, whether plots were irrigated using one or two lines of drip, one tensiometer or sensor was always located under a drip line (between two emitters) and the other was not.

Fruit from each plot were hand-picked in three harvests in 2008 and 2009 and two harvests in 2010 and weighed. In 2010, the amount of immature fruit in the second harvest was estimated by determining the weight of immature fruit as a percentage of the total.

Fruit firmness was measured using a firmness meter (FirmTech 2 Fruit Firmness Tester; BioWorks, Wamego, KS). The Compression Force Threshold procedure with a fixed range of compression forces (selected by the operator) was used to measure the grams of force required to compress the fruit $1 \mathrm{~mm}$. After load cell calibration and a reference size measurement, which is required for fruit diameter measurements, fruit were placed with the proximal end facing inward on a metal plate turntable. The instrument measured fruit firmness and diameter simultaneously at room temperature. Two runs of 50 fruit each were conducted per treatment in each block on every harvest date. Mean fruit fresh weight was also determined by counting and weighing a random sample of a minimum of 100 fruit from each plot and harvest.

Fruit shelf life was estimated by determining percent weight loss in cold storage. One hundred fruit were randomly selected from each plot and harvest, placed in perforated plastic bags, and weighed. The bags were placed as a single layer in shallow trays in a cooler at $4{ }^{\circ} \mathrm{C}$. Final weights were recorded after 1 week.

Fruit percent water content was determined by measuring fresh weight and dry weight (after oven-drying at $105^{\circ} \mathrm{C}$ for 1 week) of random samples of $\approx 12$ previously frozen fruit from each plot and harvest and was calculated as [(fresh weight - dry weight)/ fresh weight] $\times 100$.

Titratable acidity and soluble solids were measured on previously frozen fruit. Fifty grams of frozen fruit from each plot were placed in a $400-\mathrm{mL}$ beaker and allowed to thaw for $\approx 90 \mathrm{~min}$. The thawed fruit was blended for $40 \mathrm{~s}$ using a hand blender. Five grams of the blended fruit were transferred to a $50-\mathrm{mL}$ centrifuge tube and the sample was homogenized for $30 \mathrm{~s}$ using a benchtop Polytron homogenizer (Kinematica, Inc., Lucerne, Switzerland). The homogenized sample was quantitatively transferred to a $250-\mathrm{mL}$ beaker and made up to volume using deionized water. The mixture was then titrated with $0.1 \mathrm{M}$ $\mathrm{NaOH}$ to an end point of 8.1 using a TirtroLine Easy titration unit (Schott Instruments, Mainz, Germany). Titratable acidity was calculated as percent citric acid according to Eq. [1]:

$\%$ Citric Acid $=(\mathrm{mL} \mathrm{NaOH} \times \mathrm{MNaOH}$ x 0.064 x 100)/sample wt. (g)

Brix measurements of soluble solids were conducted using a sample of the thawed and blended fruit and a handheld Palette Digital Refractometer (Atago USA, Inc., Bellevue, WA).

Fresh fruit samples ( 50 berries of each treatment per plot) were frozen at $-80{ }^{\circ} \mathrm{C}$, freeze-dried, ground, and stored at $-80{ }^{\circ} \mathrm{C}$ before antioxidant analysis. Fruit antioxidant levels were estimated by measurement of oxygen radical absorbance capacity (ORAC) (Prior et al., 2003). Antioxidants were extracted by homogenizing $1 \mathrm{~g}$ of freeze-dried blueberries from each plot in a Polytron homogenizer (Kinematica, Inc.) with $20 \mathrm{~mL}$ of acetone/ water/acetic acid (70:29.5:0.5, v/v/v). The mixture was then centrifuged at $4140 g_{\mathrm{n}}$ and $4{ }^{\circ} \mathrm{C}$ for $20 \mathrm{~min}$. After centrifugation, the supernatant was transferred to a $2-\mathrm{mL}$ microtube and diluted $300 \times$ with phosphate buffer (0.075 M, pH 7.0). An Infinite F200pro Multimode Microplate reader (Tecan Group Ltd., Männedorf, Switzerland) was used for ORAC determinations. Twenty microliters of each solution was added to a well in a 96-well microplate with $200 \mu \mathrm{L}$ of $14 \mu \mathrm{M}$ fluorescein and $75 \mu \mathrm{L}$ of $2,2^{\prime}$-azobis(2-methylpropionamidine) dihydrochloride per well. Quenching of the fluorescent signal was computed as area under the curve. Results were compared with a Trolox standard curve prepared in phosphate buffer $(0.075 \mathrm{M}, \mathrm{pH} 7.0)$. ORAC values are expressed in $\mu$ mol Trolox equivalents (TE) per $100 \mathrm{~g}$ fresh or dry fruit weight.

Anthocyanin assays were conducted on the same freeze-dried samples used for ORAC determinations. Dried samples were extracted in trifluoroacetic acid, water, and methanol at a ratio of 1:30:70 $(\mathrm{v} / \mathrm{v} / \mathrm{v})$ as outlined in Barnes et al. (2009). Anthocyanin content was determined by high-performance liquid chromatography on a Dionex DX500 system using a gradient pump and ultraviolet/Vis detection at $520 \mathrm{~nm}$ (Dionex Corporation, Sunnyvale, CA). Chromatography used the Dionex Acclaim $120 \mathrm{C} 18 \quad 5.0-\mu \mathrm{m}$ analytical column $(4.6 \times 250 \mathrm{~mm})$ at a flow rate of $1.0 \mathrm{~mL} \cdot \mathrm{min}^{-1}$ and an injection volume of $5 \mu \mathrm{L}$ with column temperature at $26{ }^{\circ} \mathrm{C}$. The method closely followed Dionex Application Note 264. Quantification of anthocyanins was based on their peak areas compared with the absorbance of a cyanidin 3-glucoside external standard 
(Sigma-Aldrich Canada, Oakville, Ontario, Canada). Peak identification was based on comparison of retention times with those of standards and published data (Kalt et al., 1999). Total anthocyanin content was calculated from the sum of the nine largest peaks and expressed on a dry and fresh fruit weight basis.

Berry essential mineral concentrations were determined in berries using the same freezedried samples. Total nitrogen was determined by Leco combustion analysis and all other mineral concentrations were determined by inductively coupled plasma spectroscopy after nitric and hydrochloric acid digestion (A \& L Canada Laboratories Inc., Winnipeg, Manitoba, Canada).

After harvest was completed in 2009 and 2010, the size of each treatment plant in each plot was determined from an estimate of average canopy height and width. Plant width was measured parallel to the row. Prunings from each plot were also collected and weighed fresh early in 2010 and 2011 (after 2009 and 2010 seasons, respectively). Leaf sampling for mineral status was conducted in the second week of August in 2010. One fully developed leaf, located approximately five leaves down from a growing shoot tip, was harvested from each treatment plant in each of three randomly selected blocks. Leaves were pooled per plot and oven-dried at $60{ }^{\circ} \mathrm{C}$. Essential mineral concentrations were determined by the same methods as described for the fruit. Leaf greenness was measured with a chlorophyll meter (Model SPAD-502; Minolta
Canada Ltd., Mississauga, Ontario, Canada) on 30 July 2009 and on May 21 and 5 Aug. 2010. The measurements were conducted on the first fully developed leaf (approximately five leaves down from the growing tip) from two stems of each plant in each plot.

Statistical analysis. All statistical analyses were carried out with either the GLM model or REG procedures of SAS (SAS Institute, Cary, NC). Significant treatment effects were determined using a GLM procedure consisting of all nine individual treatments. Irrigation volume, emitter spacing, and number of irrigation line main effect comparisons were compared using orthogonal contrasts. A GLM procedure with treatments grouped by irrigation volume, emitter spacing, or number of irrigation lines was used to test for treatment interactions. All percentage data were arcsine transformed before analysis.

\section{Results and Discussion}

Irrigation and soil water availability. Rainfall was above normal during the first 2 years after planting (Fig. 1A-B). Thus, although irrigation was applied nine times in Year 1 (2007) and four times in Year 2 (2008), soil $\Psi_{\mathrm{m}}$ was always similar between irrigated and non-irrigated plots and never lower than -30 $\mathrm{kPa}$ at any time over the two growing seasons (data not shown). High rainfall explains why soil $\Psi_{\mathrm{m}}$ remained high although water provided by moderate and heavy irrigation from midJune to mid-September (20 and $40 \mathrm{~L} /$ plant, respectively) was substantially less than blueberry ET ( $270 \mathrm{~L} /$ plant $)$. It was not until June in Year 3 (2009) that soil $\Psi_{\mathrm{m}}$ differed among irrigation treatments (Fig. 2A). At this point, soil $\Psi_{\mathrm{m}}$ was lower in non-irrigated plots than irrigated plots, and the difference increased throughout the summer. By early Sept. 2009, soil $\Psi_{\mathrm{m}}$ dropped below $-90 \mathrm{kPa}$ in non-irrigated plots but remained higher than $-40 \mathrm{kPa}$ in plots irrigated throughout the summer with heavy irrigation. The relatively low rate of change observed through the season in the heavy irrigation treatments is because those treatments contributed $280 \mathrm{~L}$ of water per plant, very close to the ET value of $311 \mathrm{~L} /$ plant from mid-May to mid-September. Moderate irrigation contributed only $75 \mathrm{~L} /$ plant. Soil $\Psi_{\mathrm{m}}$ was also lower in 2009 when plots were irrigated with $5 \mathrm{~L} /$ plant than with $10 \mathrm{~L} /$ plant (Fig. 2A). The difference between the two was attributable not only to the difference in irrigation volume, but also the difference in irrigation frequency. Plants irrigated with $5 \mathrm{~L} /$ plant were watered 13 times in Year 3, whereas those irrigated with $10 \mathrm{~L} /$ plant were watered 25 times (Fig. 1C). However, trends over time in soil $\Psi_{\mathrm{m}}$ were similar in 2010 (Fig. 2B) when plots irrigated with $5 \mathrm{~L} /$ plant and were watered as often (i.e., 22 times) as those irrigated with $10 \mathrm{~L} /$ plant (Fig. 1D). Blueberry ET from mid-May to mid-September was $250 \mathrm{~L} /$ plant; during that time, moderate and heavy irrigation provided 224 and $452 \mathrm{~L} /$ plant, respectively. Hence, moderate irrigation satisfied the water requirements of the plants and heavy irrigation greatly exceeded them.
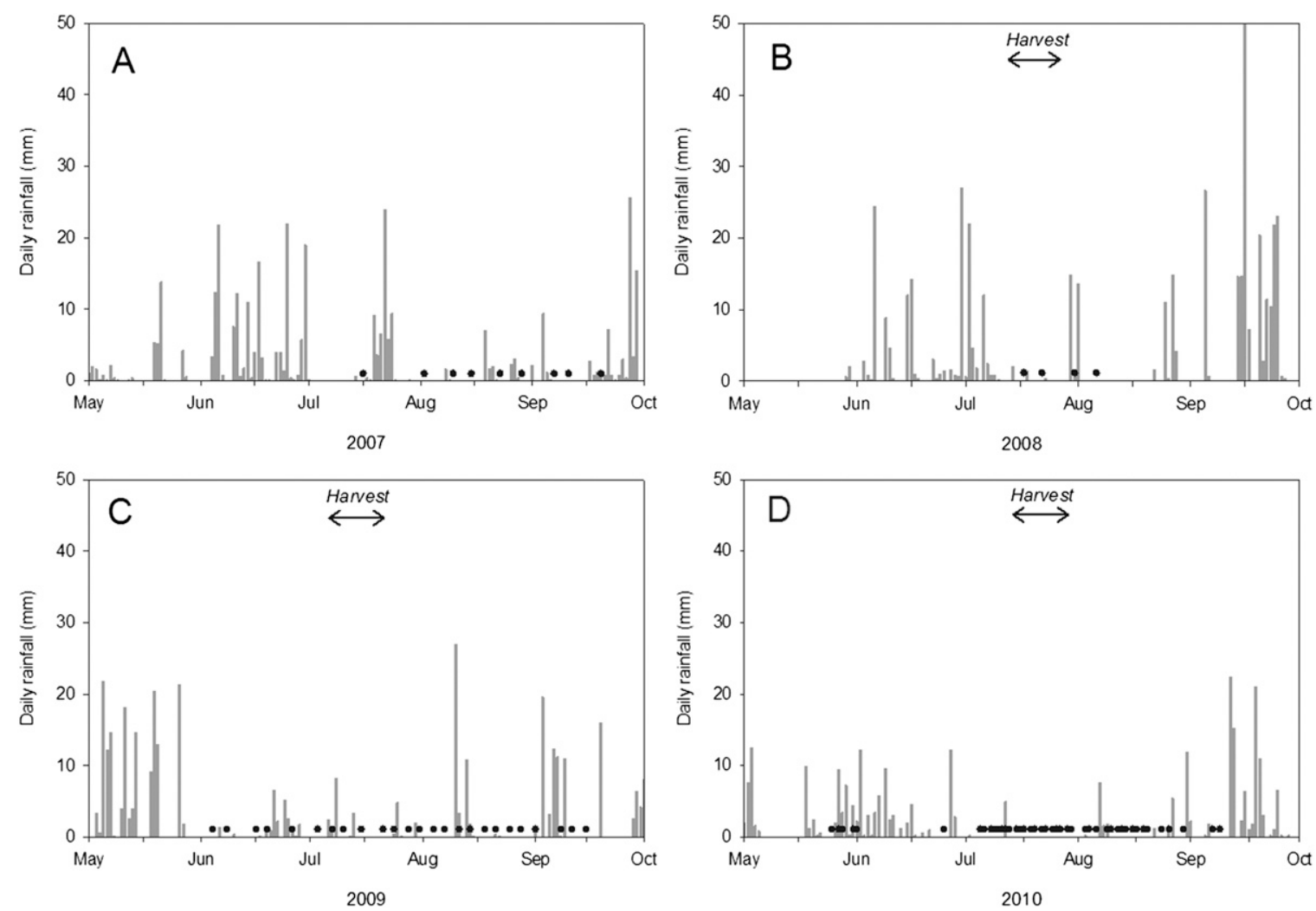

Fig. 1. Rainfall and irrigation events in 2007 (A), 2008 (B), 2009 (C), and 2010 (D). Rainfall is represented by vertical columns. Irrigation events for both moderate and heavy irrigation treatments are represented by closed circles in 2007, 2008, and 2010. In 2009, closed circles represent heavy irrigation events; moderate irrigation events were applied on 13 of those dates. Arrows indicate the period of fruit harvest. 

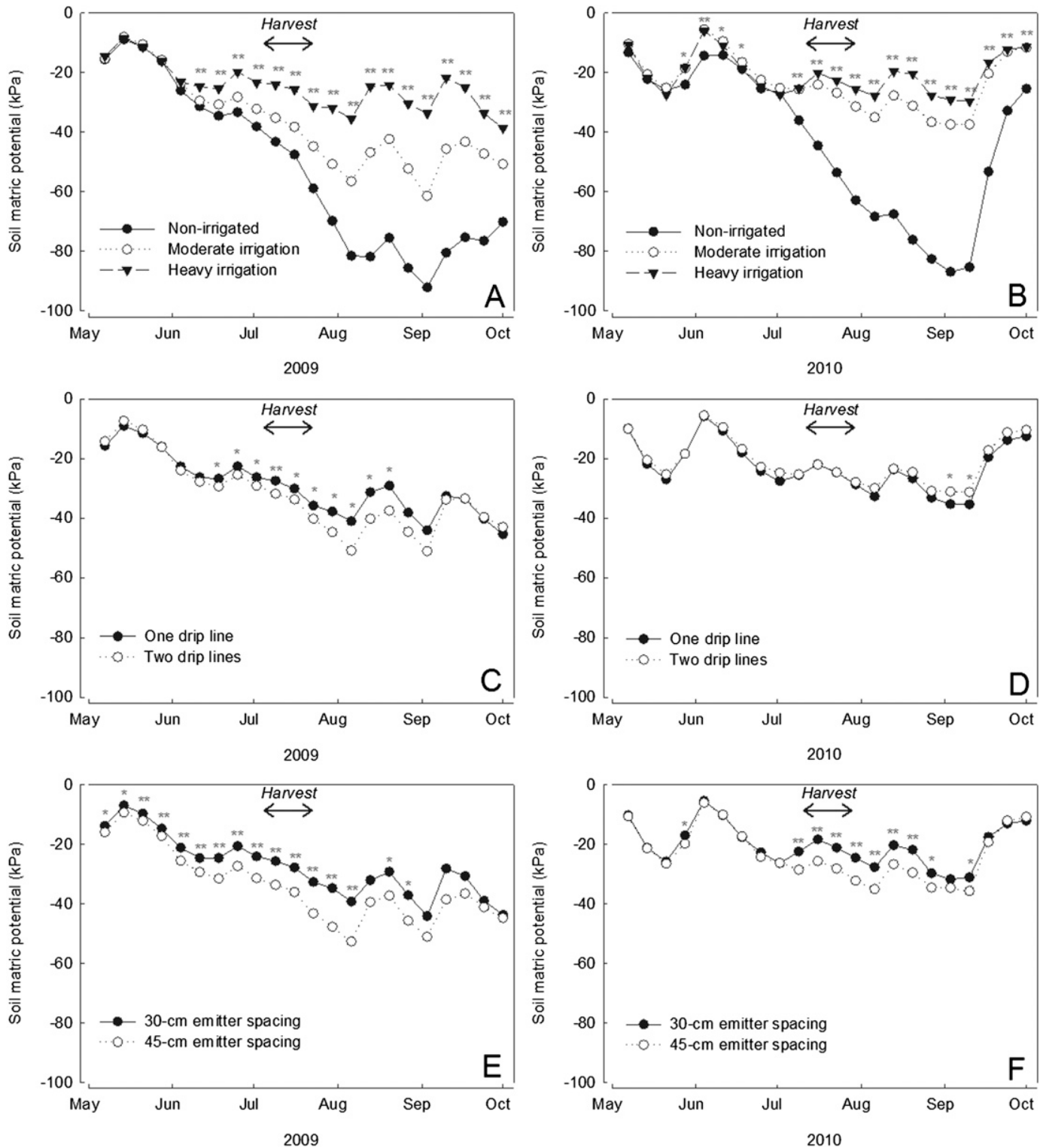

Fig. 2. Effects of irrigation level (A-B), the use of one or two drip lines (C-D), and two different drip emitter spacings ( 30 and $45 \mathrm{~cm})(\mathbf{E}, \mathbf{F})$ on soil $\Psi_{\mathrm{m}}$ under 'Duke' blueberry in 2009 (A, C, E) and 2010 (B, D, F). The single line of drip was suspended over the center of the planting bed, whereas the two lines of drip were located $19 \mathrm{~cm}$ from center on each side of the bed. Measurements were taken at $0.3-\mathrm{m}$ depth and are the average of two readings taken in the middle and $19 \mathrm{~cm}$ from the middle of the bed. Moderate $=5 \mathrm{~L} /$ plant per irrigation; heavy $=10 \mathrm{~L} /$ plant per irrigation. Asterisks indicate a significant difference in treatments at $P \leq 0.05$. Arrows indicate the period of fruit harvest. $\Psi_{\mathrm{m}}=$ matric potential.

Soil $\Psi_{\mathrm{m}}$ also differed somewhat depending on drip placement. For example, there was a period in Year 3 (2009) when overall soil $\Psi_{\mathrm{m}}$ was lower in soil irrigated with two lines than with one line (Fig. 2C). Because each treatment received the same amount of water, any differences were the result of the way water was distributed. Since the two lines were each placed midway between the center and the edge of the beds, lower soil $\Psi_{\mathrm{m}}$ was likely the result of a distribution of water over a somewhat larger soil surface area compared with the one line positioned in the center of the beds. This may be an advantage for older plants but is of no benefit to young plants with small root systems. Emitters spaced at $45 \mathrm{~cm}$ also showed lower soil $\Psi_{\mathrm{m}}$ than those spaced at $30 \mathrm{~cm}$ (Fig. 2E). It is likely that the closer emitter spacing results in a more even distribution of water over the soil surface, which is a potential benefit in a shallow-rooted crop such as blueberry (Bryla and Strik, 2007). There was no effect of the extra drip line on soil $\Psi_{\mathrm{m}}$ in 2010 (Fig. 2D), and the difference between the two emitter spacings (Fig. 2F) was less apparent than in the previous year. However, there was an extended period from late June to early September when the interaction between the number of irrigation lines and emitter spacing was significant $(P<$ 0.05 ), which indicates that the two factors were not independently influencing soil $\Psi_{\mathrm{m}}$.

Plant growth and yield. Irrigation layout, including the number of irrigation lines and emitter spacing, had no significant effect on yield or fruit quality (data not shown). Therefore, only the effects of irrigation volume on yield and fruit quality are presented.

Yield was unaffected by irrigation volume during the first 2 years of harvest (Table 1).
However, by the third year, orthogonal contrasts of the combined irrigation treatments with non-irrigated controls showed an overall benefit of irrigation on yield. Specifically, moderate irrigation produced higher yields than the non-irrigated control, but no differences were apparent between the non-irrigated and heavy irrigation treatments. Likewise, total berry dry weight per plant (calculated by multiplying total yield per plant by percent fruit dry weight) revealed a similar trend as that of yield- no differences among treatments the first 2 years but averages of 433,476 , and $459 \mathrm{~g} / \mathrm{plant}$ in the non-irrigated, moderate, and heavy irrigation treatments, respectively, in 2010. Only the moderate irrigation treatment was significantly different from the other two $(P<0.05)$. The parallel effects on total berry dry weight suggest that the increase in yield with moderate irrigation was in part a result of changes in 
carbon assimilation capacity or partitioning of carbon to the fruit and not just to changes in fruit fresh weight or fruit water content. Totaled across years, moderate irrigation improved yield compared with the non-irrigated control, but heavy irrigation did not. Effects of irrigation on blueberry yield are variable and complex and depend on such factors as soil texture, plant species, volume of water applied, plant age, and method of water application. Using a water balance approach to schedule irrigation, Byers and Moore (1987) found no effect of irrigation in trickle-irrigated highbush blueberry grown in 140-L barrels of loam soil. In a study of irrigation scheduling based on soil moisture tension, Haman et al. (1997) found no effect of irrigation on rabbiteye blueberry yield but an increase in yield in highbush plants, both grown in lysimeters filled with sand. Previous studies have also shown reduced effectiveness of heavy compared with moderate irrigation rates on blueberry yield. For example, Bryla et al. (2009) found no difference in yield between plants treated with $100 \%$ and $150 \%$ ET. In a study comparing drip with microjet irrigation, Holzapfel et al. (2004), working with plants in a loam-clay textured soil, found that although yield in the drip treatments generally increased linearly with irrigation volume, yield of the microjet treatments showed a reduction in yield at the highest application volumes. The suggestion was that heavy irrigation created detrimental anaerobic soil conditions. This possibility is supported by the observation

Table 1. Effects of irrigation level on yield in 'Duke' blueberry during the first 3 years of fruit production (2008-2010).

\begin{tabular}{|c|c|c|c|c|c|c|}
\hline & \multicolumn{4}{|c|}{ Yield by yr (kg/plant) } & \multicolumn{2}{|c|}{$\begin{array}{l}\text { Yield by harvest } \\
(\mathrm{kg} / \text { plant })^{\mathrm{y}}\end{array}$} \\
\hline & 2008 & 2009 & 2010 & Cumulative & Harvest 1 & Harvests 2 and 3 \\
\hline \multicolumn{7}{|l|}{ Irrigation level $^{z}$} \\
\hline Non-irrigated & 0.702 & 1.231 & 4.091 & 6.024 & 1.133 & 0.875 \\
\hline Moderate & 0.664 & 1.406 & 4.574 & 6.644 & 1.155 & 1.064 \\
\hline Heavy & 0.601 & 1.390 & 4.331 & 6.323 & 1.148 & 0.964 \\
\hline \multicolumn{7}{|l|}{ Contrasts } \\
\hline Non-irrigated and moderate & NS & NS & $*$ & $*$ & NS & $* *$ \\
\hline Non-irrigated and heavy & NS & NS & NS & NS & NS & NS \\
\hline Moderate and heavy & NS & NS & $*$ & NS & NS & $*$ \\
\hline Non-irrigated and irrigated & NS & NS & $*$ & NS & NS & $*$ \\
\hline
\end{tabular}

${ }^{\mathrm{z}}$ Moderate $-5 \mathrm{~L}$ per plant per irrigation; heavy - $10 \mathrm{~L}$ per plant per irrigation.

${ }^{\mathrm{y}}$ Data averaged over years.

Ns, * **Non-significant or significant at $P=0.05$ or 0.01 , respectively. irrigation volumes potentially contribute to reductions in yield.

Irrigation did not influence yield of the first harvest; the effects were observed only in later harvests, when moderate irrigation (but not heavy irrigation) increased yield (Table 1). Hence, the difference in total yield attributed to moderate irrigation seems to be the result of an increase in the weight of lateripening fruit. Furthermore, a greater percentage of total fruit weight was still immature at the last harvest in the moderate irrigation treatment compared with the control and heavy irrigation treatments $(23.1 \%$ compared with $18.8 \%$ and $18.0 \%$, respectively, $P<0.001$ ).

Plant height and width were both greater in the irrigated compared with the non-irrigated plants when measured after harvest in the third and fourth year of the trial (Table 3). There were no significant differences in pruning weights among treatments in those years with values of 159,170 , and $166 \mathrm{~g}$ per plant in the nonirrigated, moderate, and heavy irrigation treatments, respectively $(P>0.05)$. An increase in plant height and width implies greater canopy volume and possible leaf nutrient dilution with irrigation as discussed previously. Additionally, plant height was greater in the highly irrigated compared with the moderately irrigated plants. As a result, although there was no improvement in yield after 4 years of heavy irrigation, the greater plant size observed in the last 2 years could potentially boost yield in subsequent years.

Fruit quality. Fruit quality is important in the marketplace with fruit size being an obvious attribute noticed by consumers. Fruit size measured as fresh weight was unaffected by irrigation in 2008 (Table 4). Heavy irrigation increased fruit size in 2009 relative to nonirrigated controls. In 2010, both moderate and heavy irrigation increased fruit size compared with the non-irrigated controls. When averaged across all years, mean fruit size increased with increasing irrigation. Fruit size is an important aspect of blueberry marketing so any increase in size would be viewed by the industry as a positive outcome of irrigation. The lack of effect of irrigation in the first year of harvest was similar to the results of Byers and Moore (1987) who found that blueberry size was unaffected by drip irrigation scheduling. In our study, the effects of irrigation on fruit size appeared to manifest as the plants matured.

Table 2. Effects of irrigation level on leaf nutrient concentration in 'Duke' blueberry.

\begin{tabular}{|c|c|c|c|c|c|c|c|c|c|c|c|}
\hline & \multicolumn{6}{|c|}{ Leaf macronutrients $\left(\mathrm{mg} \cdot \mathrm{g}^{-1}\right)$} & \multicolumn{5}{|c|}{ Leaf micronutrients $\left(\mu \mathrm{g} \cdot \mathrm{g}^{-1}\right)$} \\
\hline & Nitrogen & Sulfur & Phosphorus & Potassium & Magnesium & Calcium & Boron & Zinc & Manganese & Iron & $\overline{\text { Copper }}$ \\
\hline \multicolumn{12}{|l|}{ Irrigation level $^{\mathrm{y}}$} \\
\hline Non-irrigated & 17.6 & 1.37 & 1.10 & 5.40 & 2.00 & 7.30 & 76.3 & 13.3 & 374 & 95.3 & 10.7 \\
\hline Moderate & 16.8 & 1.28 & 1.08 & 5.11 & 1.79 & 6.33 & 69.8 & 12.0 & 292 & 91.3 & 10.2 \\
\hline Heavy & 16.5 & 1.26 & 1.11 & 5.17 & 1.84 & 6.46 & 64.6 & 13.8 & 265 & 91.3 & 11.8 \\
\hline \multicolumn{12}{|l|}{ Contrasts } \\
\hline Non-irrigated and moderate & NS & NS & NS & NS & $*$ & $*$ & NS & NS & $*$ & NS & NS \\
\hline Non-irrigated and heavy & $*$ & NS & NS & NS & NS & NS & $*$ & NS & $* *$ & NS & NS \\
\hline Moderate and heavy & NS & NS & NS & NS & NS & NS & NS & $*$ & NS & NS & $*$ \\
\hline Non-irrigated and irrigated & NS & NS & NS & NS & NS & $*$ & NS & NS & $* *$ & NS & NS \\
\hline
\end{tabular}

${ }^{\mathrm{z}}$ Leaves were sampled in Aug. 2010 during the fourth year after planting.

${ }^{\mathrm{y}}$ Moderate $=5 \mathrm{~L}$ per plant per irrigation; heavy $=10 \mathrm{~L}$ per plant per irrigation.

Ns, ${ }^{*}, * *$ Non-significant or significant at $P=0.05$ or 0.01 , respectively. 
Others have also shown that berries are larger in irrigated plants. Increasing irrigation from $50 \%$ to $100 \%$ of the crop's ET requirements improved berry size, although no further increases were observed at $150 \%$ ET (Bryla et al., 2009). The opposite effect has also been found. In a study examining the effects of water stress on blueberry harvest the next year, Mingeau et al. (2001) showed that a 20-d stress period during flower induction reduced flower buds and produced fewer, but larger fruit the next season. In our study, no treatment differences were observed in the number of berries per plant; means were 349, 500, and 2103 berries per plant in 2008, 2009, and 2010, respectively. This differs from other studies, in which irrigation increased the number of berries per bush (Haman et al., 1997; Holzapfel

Table 3. Effects of irrigation level on plant growth in 'Duke' blueberry.

\begin{tabular}{|c|c|c|}
\hline & $\begin{array}{l}\text { Plant width } \\
(\mathrm{cm})\end{array}$ & $\begin{array}{l}\text { Plant ht } \\
\text { (cm) }\end{array}$ \\
\hline \multicolumn{3}{|l|}{ Irrigation level $^{\mathrm{y}}$} \\
\hline Non-irrigated & 67.3 & 108.1 \\
\hline Moderate & 71.1 & 116.8 \\
\hline Heavy & 70.8 & 120.5 \\
\hline \multicolumn{3}{|l|}{ Contrasts } \\
\hline $\begin{array}{l}\text { Non-irrigated } \\
\text { and moderate }\end{array}$ & $* *$ & $* * *$ \\
\hline $\begin{array}{l}\text { Non-irrigated } \\
\text { and heavy }\end{array}$ & $* *$ & $* * *$ \\
\hline Moderate and heavy & NS & $* *$ \\
\hline $\begin{array}{l}\text { Non-irrigated } \\
\text { and irrigated }\end{array}$ & $* *$ & $* * *$ \\
\hline
\end{tabular}

zPlants were measured in 2009 and 2010, following the third and fourth year after planting, and values were averaged over the two growing seasons.

${ }^{\mathrm{y}}$ Moderate $=5 \mathrm{~L}$ per plant per irrigation; heavy $=10$ $\mathrm{L}$ per plant per irrigation.

Ns, **,***Non-significant or significant at $P=0.01$ or 0.001 , respectively. et al., 2004). Therefore, any effects of irrigation on fruit size in our study were the result of direct effects on the fruit rather than changes in fruit load.

Fruit firmness is another quality attribute desired by consumers. Fruit were not as firm in the heavy irrigation treatment as in the control and moderate irrigation treatments in 2008 (Table 4). In 2009 and 2010, there was no effect of irrigation. Taking all years into consideration, fruit firmness was reduced in the heavy irrigation treatment compared with non-irrigation but moderate irrigation had no effect. Bryla (2008) found that increasing irrigation of blueberry reduced fruit firmness and increased fruit size; our observations support that finding. However, regression of individual fruit firmness against fruit diameter using all our samples shows no relationship between the two $\left(R^{2}=0.003, P>0.05\right.$, $\mathrm{n}=486$ samples of 100 fruit each) nor were there significant relationships in individual regressions from non-irrigated, moderate, and heavy irrigation treatments (data not shown). Therefore, reductions in firmness and increase in size caused by irrigation are not necessarily related to each other. This observation is supported by two studies of strawberry (Fragaria $\times$ ananassa). Krüger et al. (2002) found that irrigation resulted in larger but less firm fruit. However, the relationship was not consistent from year to year; in 1 of 2 years, the firmness of irrigated fruit decreased with no change in fruit size, suggesting that changes in firmness resulting from irrigation need not always be associated with changes in fruit size. Similarly, Hoppula and Salo (2007) found that despite a decrease in fruit firmness with irrigation, there was no significant effect on strawberry fruit size.

Irrigation did not affect fruit soluble solids values in 2008 and 2010 (Table 4). In 2009, soluble solids values were highest in the nonirrigated control, decreasing with increasing irrigation. There was also a volume $\times$ lines interaction $(P<0.01)$. When all years were considered together, there was an overall effect of irrigation and the heavy irrigation treatment was significantly different from the nonirrigated control. Bryla et al. (2009) showed a similar reduction in blueberry soluble solids with increasing irrigation, but the effect was more pronounced in sprinkler and microspray treatments than in drip. Byers and Moore (1987) found no effect of drip irrigation scheduling on blueberry soluble solids. For comparative purposes, non-irrigated grapes (Vitis vinifera L.) have been found to accumulate berry sugar more rapidly than irrigated vines (Freeman et al., 1980). However, the opposite effect was found in strawberry, in which irrigation increased soluble solids content (Hoppula and Salo, 2007).

Fruit percent water content was unaffected by irrigation in 2008 and 2010 (Table 4). In 2009 , fruit percent water content was significantly increased in the heavy irrigation treatment compared with the control. Averaged across years, both irrigation treatments showed increased percent water content compared with the non-irrigated control. This, along with the overall reduction in soluble solids content at heavy irrigation, suggests that heavy irrigation dilutes fruit dry weight because of increased water content.

As with fresh weight, soluble solids, and percent dry weight, no effects of irrigation on fruit acidity were found in 2008 (Table 4). In 2009 , the overall effect of irrigation was to reduce acidity with heavily irrigated fruit specifically being less acidic than control fruit. In 2010, the opposite result was observed with the heavy irrigation treatment showing the highest acidity. Averaged across years, heavy

Table 4. Effects of irrigation level on fruit quality in 'Duke' blueberry during the first 3 years of fruit production (2008-2010).

\begin{tabular}{|c|c|c|c|c|c|c|c|c|c|c|c|c|}
\hline & \multicolumn{4}{|c|}{ Firmness $\left(\mathrm{g} \cdot \mathrm{mm}^{-1}\right)$} & \multicolumn{4}{|c|}{ Berry wt (g) } & \multicolumn{4}{|c|}{ Soluble solids ( ${ }^{\circ}$ Brix $)$} \\
\hline & 2008 & 2009 & 2010 & Mean & 2008 & 2009 & 2010 & Mean & 2008 & 2009 & 2010 & Mean \\
\hline \multicolumn{13}{|l|}{ Irrigation level ${ }^{\mathrm{z}}$} \\
\hline Non-irrigated & 187.2 & 176.5 & 174.6 & 179.4 & 1.87 & 2.62 & 1.98 & 2.16 & 12.8 & 12.3 & 11.5 & 12.1 \\
\hline Moderate & 182.8 & 175.6 & 174.9 & 177.8 & 1.89 & 2.70 & 2.09 & 2.23 & 12.7 & 11.9 & 11.3 & 11.9 \\
\hline Heavy & 175.8 & 175.8 & 171.4 & 174.3 & 1.92 & 2.77 & 2.12 & 2.27 & 12.6 & 11.6 & 11.5 & 11.9 \\
\hline \multicolumn{13}{|l|}{ Contrasts } \\
\hline Non-irrigated and moderate & NS & NS & NS & NS & NS & NS & $*$ & $*$ & NS & $*$ & NS & NS \\
\hline Non-irrigated and heavy & $*$ & NS & NS & $*$ & NS & $* *$ & $* *$ & $* * *$ & NS & $* *$ & NS & $*$ \\
\hline Moderate and heavy & NS & NS & NS & $*$ & NS & $*$ & NS & $*$ & NS & $* *$ & NS & NS \\
\hline \multirow[t]{3}{*}{ Non-irrigated and irrigated } & NS & NS & NS & NS & NS & $*$ & $* *$ & $* * *$ & NS & $* *$ & NS & $*$ \\
\hline & \multicolumn{4}{|c|}{ Water content $(\%)^{\mathrm{y}}$} & \multicolumn{4}{|c|}{ Titratable acidity $(\%)^{\mathrm{y}}$} & \multicolumn{4}{|c|}{ Storage water loss $(\%)^{\mathrm{y}}$} \\
\hline & 2008 & 2009 & 2010 & Mean & 2008 & 2009 & 2010 & Mean & 2008 & 2009 & 2010 & Mean \\
\hline \multicolumn{13}{|l|}{ Irrigation level ${ }^{\mathrm{z}}$} \\
\hline Non-irrigated & 85.1 & 88.5 & 89.4 & 87.7 & 0.80 & 0.81 & 0.39 & 0.67 & 1.54 & 2.58 & 3.80 & 1.58 \\
\hline Moderate & 85.3 & 88.9 & 89.6 & 87.9 & 0.80 & 0.77 & 0.39 & 0.65 & 1.30 & 2.45 & 3.91 & 1.49 \\
\hline Heavy & 85.2 & 89.2 & 89.4 & 87.9 & 0.83 & 0.75 & 0.44 & 0.68 & 1.21 & 2.30 & 3.95 & 1.45 \\
\hline \multicolumn{13}{|l|}{ Contrasts } \\
\hline Non-irrigated and moderate & NS & NS & NS & $*$ & NS & NS & NS & NS & $*$ & NS & NS & NS \\
\hline Non-irrigated and heavy & NS & $* *$ & NS & $*$ & NS & $*$ & $*$ & NS & $*$ & $*$ & NS & NS \\
\hline Moderate and heavy & NS & NS & NS & NS & NS & NS & $* * *$ & $*$ & NS & NS & NS & NS \\
\hline Non-irrigated and irrigated & NS & NS & NS & $*$ & NS & $*$ & NS & NS & $*$ & NS & NS & NS \\
\hline
\end{tabular}

${ }^{\mathrm{z}}$ Moderate $=5 \mathrm{~L}$ per plant per irrigation; heavy $=10 \mathrm{~L}$ per plant per irrigation.

${ }^{\mathrm{y}}$ Data arcsine transformed before statistical analysis.

NS, $* * *, * * *$ Non-significant or significant at $P=0.05,0.01$, or 0.001 , respectively. 
Table 5. Effects of irrigation level on the anthocyanin composition of fruit harvested in 2010.

Delphinidin Cyanidin Delphinidin Petunidin $\quad$ Cyanidin $\quad$ Peonidin $\quad$ Petunidin Malvidin Malvidin

3-galactoside 3-galactoside 3-arabinoside 3-galactoside 3-arabinoside 3-galactoside 3-arabinoside 3-galactoside 3-arabinoside

\begin{tabular}{|c|c|c|c|c|c|c|c|c|c|}
\hline \multicolumn{10}{|l|}{ Irrigation level ${ }^{z}$} \\
\hline Non-irrigated & 17.0 & 2.5 & 9.2 & 12.4 & 1.3 & 2.5 & 6.1 & 33.7 & 15.3 \\
\hline Moderate & 16.5 & 2.6 & 8.7 & 12.3 & 1.2 & 2.3 & 5.7 & 35.0 & 15.6 \\
\hline Heavy & 17.2 & 2.7 & 9.2 & 12.5 & 1.3 & 2.5 & 5.8 & 33.6 & 15.1 \\
\hline \multicolumn{10}{|l|}{ Contrasts } \\
\hline $\begin{array}{l}\text { Non-irrigated } \\
\text { and moderate }\end{array}$ & NS & NS & * & NS & $*$ & NS & NS & $*$ & NS \\
\hline $\begin{array}{l}\text { Non-irrigated } \\
\text { and heavy }\end{array}$ & NS & NS & NS & NS & NS & NS & NS & NS & NS \\
\hline Moderate and heavy & $*$ & NS & ** & NS & ** & NS & NS & ** & $*$ \\
\hline $\begin{array}{l}\text { Non-irrigated } \\
\text { and irrigated }\end{array}$ & NS & NS & NS & NS & NS & NS & NS & NS & NS \\
\hline
\end{tabular}

${ }^{\mathrm{z}}$ Moderate $=5 \mathrm{~L}$ per plant per irrigation; heavy $=10 \mathrm{~L}$ per plant per irrigation.

NS, $* * *$ Non-significant or significant at $P=0.05$ or 0.01 , respectively. Data were arcsine transformed before statistical evaluation.

irrigation produced fruit with slightly higher acidity than those of moderate irrigation. Bryla et al. (2009) also found a complex interaction between titratable acidity and method of irrigation, which varied by year, and Byers and Moore (1987) found no effect of irrigation on titratable acidity at all. Hence, the effects of irrigation on blueberry acidity are not clear.

Unlike many of the other fruit quality parameters, fruit shelf life was influenced by irrigation treatment in the first year of harvest (2008). Both moderate and heavy irrigation fruit showed reduced water loss in storage compared with the non-irrigated control fruit, leading to an overall effect of improved shelf life as a result of irrigation (Table 4). However, in 2009, only the heavy irrigation treatment showed reduced water loss compared with the control fruit, and in 2010, there was no effect of irrigation at all. There were no overall effects of irrigation on shelf life when averaged across all years. Treatment differences in fruit size could be part of the explanation for reduced water loss in the irrigated treatments by virtue of the fact that irrigated fruit tended to be larger and therefore had a smaller surface to volume ratio, which would reduce evaporation. However, this was not the case in 2008, when differences in water loss were the most evident. To our knowledge, no other literature on blueberries is available and our results differ from information on other fruit in storage. For example, water loss during storage was initially greater in irrigated hot peppers (Capsicum annum L.) compared with those exposed to either deficit irrigation or root zone drying, although the differences eventually disappeared with time in storage (Dorji et al., 2005). Similarly, water loss in peaches (Prunus persica L. Batsch) during storage increased with irrigation from deficit to optimum to excess (Crisosto et al., 1994).

Nutritional health benefits are an increasingly important aspect of fruit quality. Irrigation treatments did not influence antioxidant levels in the fruit. Averaged among all treatments, ORAC was $484 \mu \mathrm{mol} \mathrm{TE} / \mathrm{g}$ and $38 \mu \mathrm{mol}$ TE/g expressed on a dry weight and fresh weight basis, respectively. These values are higher than those reported in a study of highbush blueberry cultivars (Ehlenfeldt and
Prior, 2001) in which ORAC values for 'Duke' were $16.1 \mu \mathrm{mol} \mathrm{TE} / \mathrm{g}$ fresh weight and values for 87 cultivars ranged from $4.6 \mu \mathrm{mol} \mathrm{TE} / \mathrm{g}$ to $31.1 \mu \mathrm{mol} \mathrm{TE} / \mathrm{g}$ fresh weight. Anthocyanins are also important health components of blueberry fruit. Irrigation did not influence total anthocyanin content (grand means of $11.2 \mathrm{mg} \cdot \mathrm{g}^{-1}$ and $1.40 \mathrm{mg} \cdot \mathrm{g}^{-1}$ dry and fresh weight, respectively, $P>0.05$ ), and values were somewhat lower than those reported for 'Duke' (2.16 $\mathrm{mg} \cdot \mathrm{g}^{-1}$ fresh weight) by Ehlenfeldt and Prior (2001). However, irrigation resulted in a change in anthocyanin composition (Table 5). Moderate irrigation reduced delphinidin 3-arabinoside and cyanidine 3-arabinoside and increased malvidin 3 -galactoside and malvidin 3-arabinoside compared with both non-irrigation and heavy irrigation. Additionally, moderate irrigation reduced delphinidin 3-galactoside compared with heavy irrigation. It is not known how these changes reflect nutritional value, but they demonstrate the potential for irrigationinduced changes in anthocyanin metabolism. Minerals are also important health components of fruit. Moderate irrigation resulted in higher fruit sulfur, phosphorus, and potassium $(\mathrm{K})\left(0.585,0.949\right.$, and $7.36 \mathrm{mg} \cdot \mathrm{g}^{-1}$ dry weight, respectively) than found under heavy irrigation $\left(0.554,0.909\right.$, and $7.05 \mathrm{mg} \cdot \mathrm{g}^{-1}$ dry weight, with $P<0.01,0.05$, and 0.05 , respectively). Moderate irrigation also increased $\mathrm{K}$ compared with the non-irrigated control $\left(6.98 \mathrm{mg} \cdot \mathrm{g}^{-1}\right.$ dry weight, $\left.P<0.05\right)$. These observations differ from the effects of irrigation on leaf mineral concentrations in two respects: leaf mineral concentrations tended to be the lowest with moderate irrigation and the minerals, which changed in concentration, were entirely different. Apart from the improvements in fruit nutritional value resulting from these increments in mineral concentrations, it is unknown if the changes play a role in the observed treatment differences in other fruit parameters such as firmness, size, or soluble solids content. In that regard, it is interesting that $\mathrm{Ca}$, which has been associated with fruit firmness (Pinheiro and Almeida, 2008; Siddiqui and Bangerth, 1995), was not influenced by irrigation (data not shown).
It is interesting to note that irrigation effects on fruit quality were in many cases observed 1 or 2 years before effects on yield and at times when treatment differences in $\Psi_{\mathrm{m}}$ were not obvious. This suggests that many of the attributes of fruit quality are more sensitive to the effects of water stress than is yield. Whereas yield may be influenced by cumulative differences in plant size or root distribution brought on by years of irrigation, it seems that parameters of fruit quality such as firmness, chemical composition, and shelf life are more likely to be affected by irrigation practices and plant water status in the current season. This is not to say that yield is unaffected by current-season water status. In a study of the timing of water deficit in blueberries, Mingeau et al. (2001) found that reducing water application at specific times in fruit development reduced yield in the current season and, depending on the period during which water deficit was applied, also in the next season.

\section{Literature Cited}

Barnes, J.S., H.P. Nguyen, S. Shen, and K.A. Schug. 2009. General method for extraction of blueberry anthocyanins and identification using high performance liquid chromatography-electrospray ionization-ion trap-flight-mass spectrometry. J. Chromatography 1216:4728-4735.

BCMAL. 2009. Berry production guide. BC Ministry of Agriculture and Lands, Victoria, British Columbia, Canada.

Bryla, D.R. 2008. Water requirements of young blueberry plants irrigated by sprinklers, microsprays and drip. Acta Hort. 792:135-139.

Bryla, D.R., J.L. Gartung, and B.C. Strik. 2011 Evaluation of irrigation methods for highbush blueberry-I. Growth and water requirements of young plants. HortScience 46:95-101.

Bryla, D.R. and R.G. Linderman. 2007. Implications of irrigation method and amount of water application on Phytophthora and Pythium infection and severity of root rot in highbush blueberry. HortScience 42:1463-1467.

Bryla, D.R. and B.C. Strik. 2007. Effects of cultivar and plant spacing on the seasonal water requirements of highbush blueberry. J. Amer. Soc. Hort. Sci. 132:270-277.

Bryla, D.R., B. Yorgey, and A.D. Shireman. 2009. Irrigation management effects on yield and fruit quality of highbush blueberry. Acta Hort. 810:649-656. 
Byers, P.L. and J.N. Moore. 1987. Irrigation scheduling for young highbush blueberry plants in Arkansas. HortScience 22:52-54.

Crisosto, C.H., R.S. Johnson, J.G. Luza, and G.M Crisosto. 1994. Irrigation regimes affect fruit soluble solids concentration and rate of water loss of 'O'Henry' peaches. HortScience 29: 1169-1171.

Dorji, K., M.H. Behboudian, and J.A. ZegbeDomínguez. 2005. Water relations, growth, yield, and fruit quality of hot pepper under deficit irrigation and partial rootzone drying. Sci. Hort. 104:137-149.

Ehlenfeldt, M. and R.L. Prior. 2001. Oxygen radical absorbance capacity (ORAC) and phenolic and anthocyanin concentrations in fruit and leaf tissues of highbush blueberry. J. Agr. Food Chem. 49:2222-2227.

Freeman, B.M., T.H. Lee, and C.R. Turkington. 1980. Interaction of irrigation and pruning level on grape and wine quality of Shiraz vines. Amer. J. Enol. Viticult. 31:124-135.

Haman, D.Z., A.G. Smajstrla, R.T. Pritchard, and P.M. Lyrene. 1997. Response of young blueberry plants to irrigation in Florida. HortScience 32: 1194-1196.

Holzapfel, E.A., R.F. Hepp, and M.A. Mariño. 2004. Effect of irrigation on fruit production in blueberry. Agr.Water Mgt. 67:173-184.

Hoppula, K.I. and T.J. Salo. 2007. Tensiometerbased irrigation scheduling in perennial strawberry cultivation. Irrig. Sci. 25:401-409.

Kalt, W. and D. Dufour. 1997. Health functionality of blueberries. HortTechnology 7:216-221.

Kalt, W., J.E. McDonald, R.D. Ricker, and X. Lu. 1999. Anthocyanin content and profile within and among blueberry species. Can. J. Plant Sci. 79:617-623.

Krüger, E., G. Schmidt, and S. Rasim. 2002. Effect of irrigation on yield, fruit size and firmness of strawberry cv. Elsanta. Acta Hort. 567:471-474.

Mingeau, M., C. Perrier, and T. Améglio. 2001. Evidence of drought-sensitive periods from flowering to maturity on highbush blueberry. Sci. Hort. 89:23-40.

Pinheiro, S.C.F. and D.P.F. Almeida. 2008. Modulation of tomato pericarp firmness through $\mathrm{pH}$ and calcium: Implications for the texture of fresh-cut fruit. Postharvest Biol. Technol. 47: 119-125.

Prior, R.L., H. Hoang, L. Gu, X. Wu, M. Bacchiocca, L. Howard, M. Hampsch-Woodill, D. Huang, B. Ou, and R. Jacob. 2003. Assays for hydrophilic and lipophilic antioxidant capacity [oxygen radical absorbance capacity $\left.\left(\mathrm{ORAC} \mathrm{CL}_{\mathrm{FL}}\right)\right]$ of plasma and other biological and food samples. J. Agr. Food Chem. 51:3273-3279.

Siddiqui, S. and F. Bangerth. 1995. Effect of pre-harvest application of calcium on flesh firmness and cell-wall composition of applesInfluence of fruit size. J. Hort. Sci. 70:263269.

Storlie, C.A. and P. Eck. 1996. Lysimeter-based crop coefficients for young highbush blueberries. HortScience 31:819-822.

Strik, B.C. and D. Yarborough. 2005. Blueberry production trends in North America, 1992 to 2003, and predictions for growth. HortTechnology 15:391-398.

Van der Gulik, T. 1999. BC trickle irrigation manual. BC Ministry of Agriculture and Food. Abbotsford, British Columbia, Canada. 